\title{
Innovation of Digital Learning to Enhance the Accounting Student's Performance
}

\author{
Nujmatul Laily ${ }^{1, *}$ Eka Ananta Sidharta ${ }^{2,}$ Aulia Herdiani ${ }^{3,}$ Lutfi Ardhani ${ }^{4}$
}

\author{
1,2,3 Universitas Negeri Malang \\ ${ }^{4}$ UIN Maulana Malik Ibrahim Malang \\ *Corresponding author: nujmatul.laily.fe@um.ac.id
}

\begin{abstract}
IT has an important role in education. The increase of interest in the use of e-learning into teaching and learning become a crucial part. Edmodo is one of the learning media platforms that can be accessed for free. Edmodo is known as "The Facebook of Education". This study aims to explore the implementation of Edmodo based learning in the Auditing course and to know the preferences of student using Edmodo. The research method used quantitative and qualitative to analyze the student's perception of the implementation of Edmodo based learning. Data was collected by using questionnaires, interviews, and evaluation of the student's task. The results of the study indicate that students can easily understand the features available in Edmodo because they are similar to Facebook, students feel they can easily communicate with lecturers and friends and easily access teaching materials sent by lecturers. The results also show that they enjoy using this platform because they can discuss their tasks using this media.
\end{abstract}

Keywords: Component, Formatting, Style, Styling

\section{INTRODUCTION}

IT developments require lecturers to change their old paradigms in teaching. The use of IT has become an inseparable part of the teaching and learning process in higher education [1]. Students from this era are a different generation from the previous one because they were born in an era of technological change. This generation is known as "digital native" [2]. They spend their time using computers, the internet, smartphones and others. Therefore, they will be very easy to adapt to the use of IT in teaching and learning. This is supported by research conducted by Bawaneh [1] which found empirical evidence that the use of IT in Management Accounting courses can improve student learning outcomes. Conversely, Seethamraju [3] claims that IT integration in accounting subjects such as financial accounting, management accounting, and auditing is still very limited.

One digital platform that can be used in learning is edmodo-based e-learning. Edmodo is one of the social networking platforms used specifically in learning. Edmodo is known as Facebook for education because its appearance and features on Edmodo are almost the same as those on Facebook. This will greatly facilitate students to use it in online classes. Edmodo is claimed to be a social learning platform that makes students enjoy taking online classes [4] and can improve student's performance [5]. The results of previous studies prove that the use of Edmodo-based learning media can also increase student honesty and student confidence Hanum et al. [6] also provide empirical evidence that Edmodo can improve student participation because students can participate in online class such as discussing with friends so that Edmodo can improve the closeness of relations between students and lecturers. This is supported by the research of Balasubramanian et al. [4] which provides empirical evidence that students are more interested in using Edmodo-based learning media because they can discuss in online forums. Based on this background, this study aims to determine the implementation and preferences of students using Edmodo for audit courses.

\section{METHODS}

This research uses quantitative and qualitative analysis. Quantitative analysis is used to determine the level of student preference when using Edmodo. Data collection was done using a questionnaire with a 4-point Likert scale consisting of strongly agree, agree, disagree and disagree. The research respondents were 130 students majoring in accounting. The sampling method uses purposive sampling. Students who 
became the research sample were students who had used Edmodo and were pursuing an Audit course. Students are asked to give opinions about their preferences using Edmodo including resource sharing, activities on Edmodo, features on Edmodo and evaluations. Then, the data are analyzed and grouped according to RASE (Resource, Activity, Support, Evaluation) to find out the highest student preferences. Whereas qualitative analysis was carried out to deepen research findings by conducting in-depth interviews with 25 informants.

\section{RESULTS AND DISCUSSIONS}

\subsection{Edmodo Implementation in Audit Courses}

First of all, students are introduced to edmodo-based learning media. Students are instructed to open the edmodo.com website and are asked to create an account on edmodo for the class they are taking by entering the class code that has been created by the lecturer. Students are very enthusiastic about creating an account on Edmodo because the appearance of Edmodo is similar to Facebook. Students can easily understand the features in Edmodo. Following is the display of one of the student accounts.

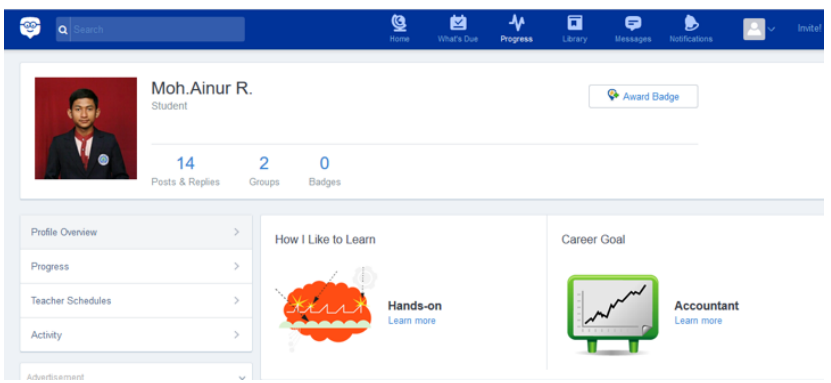

Figure 1 Example of a student account on Edmodo

After students have an account at edmodo, the next step is to introduce more in-depth features and ways to use edmodo. First, students were given an announcement regarding the course syllabus that was followed and students were asked to download the syllabus from Edmodo. If there are questions or problems related to the syllabus, students can click "replay" on the Edmodo wall. The following is an edmodo wall display when the lecturer sends a syllabus in the form of a docx file. and the response of students who "like".

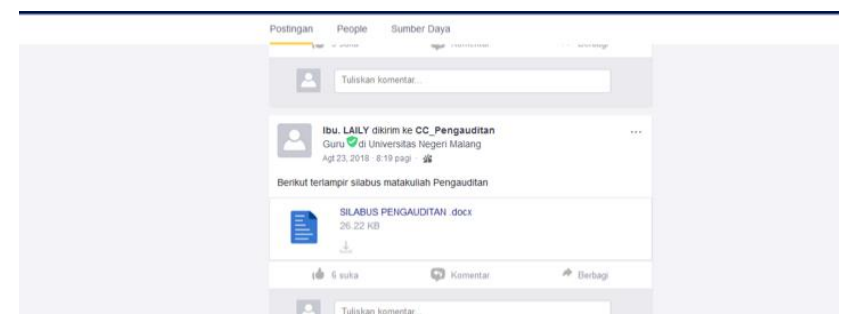

Figure 2 Student responses when the lecturer sends syllabus

Edmodo is very effective when lecturers want to provide assignments for students where the lecturer can save assignment files in the "library" and this media also makes it easier for students to submit assignments. Assignments can be given in the assignment menu and lecturers can set the duration of students to do the assignment. In addition, students can also discuss with each other, provide comments and questions through the wall because it's the same as on Facebook. All student activities will be transparently monitored by the lecturer as follows:

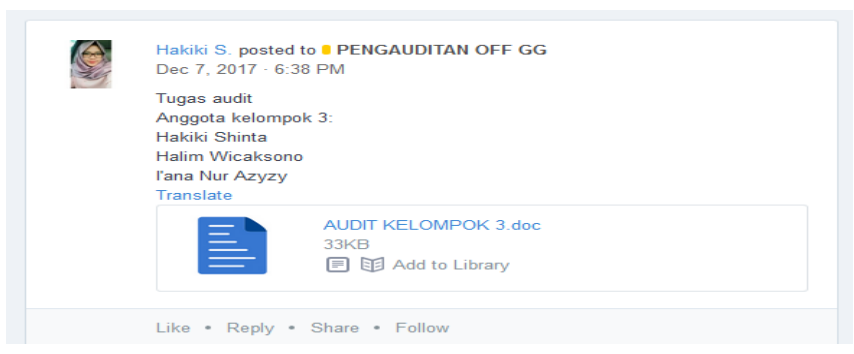

Figure 3 Students sending assignments via Edmodo

Edmodo also has a QUIZ feature that can be used by lecturers to make quizzes, midterm and final exam. The form of questions can be multiple choice, short answers, true false, match or essay questions. By using this feature, lecturers do not need to calculate the scores generated by students because Edmodo has automatically generated these scores. However, this only applies to multiple choice questions, true false, concise and matching answers. Students are very happy to use this media when midterm or midterm because they can find the correct answers after completing the quiz and immediately know their grades. Following are the QUIZ that have been conducted by lecturers:

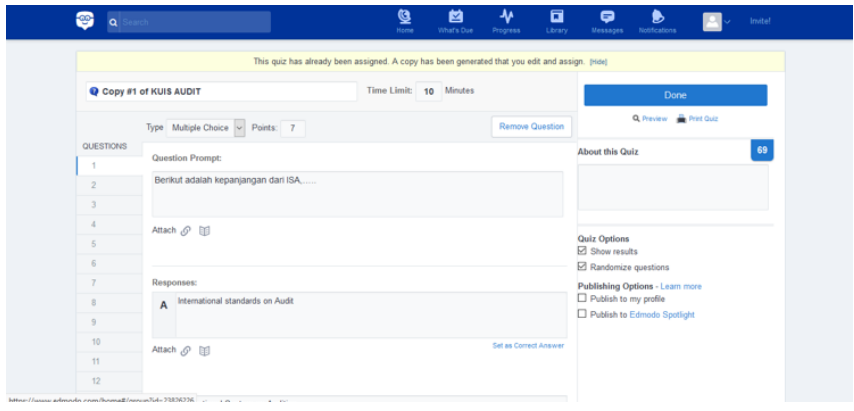

Figure 4 Quiz features with multiple choice questions

After the lecturer makes the questions, the lecturer posts the quiz so that it can be accessed by students. From the following picture it appears that there are 32 students who have already worked on the quiz and the number of questions is 33 questions. In this feature, lecturers can provide restrictions and duration of the quiz so that Edmodo will close automatically if the duration of working on the quiz exceeds what has been determined by the lecturer. Questions can also be randomized by the system automatically. 


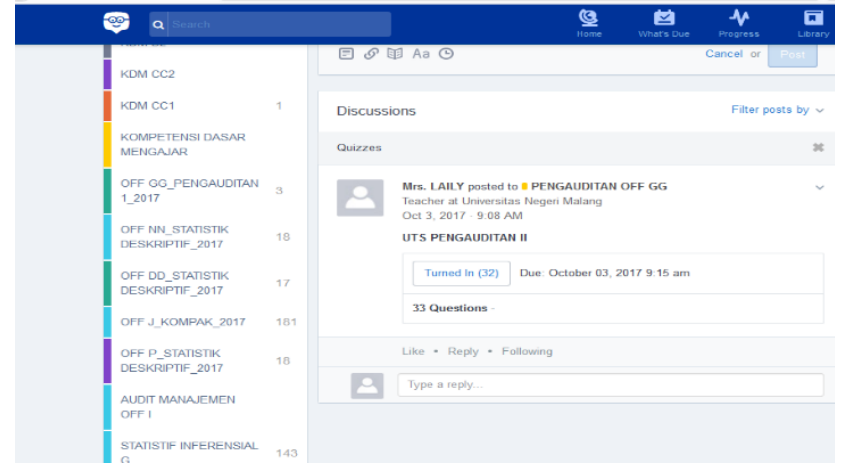

Figure 5 Posting Quiz via Edmodo

\subsection{Student Preferences Using Edmodo as a Resource Sharing}

To measure the level of student preferences about edmodo as a resource sharing forum, there are 5 indicators used namely ease of identifying teaching materials, ease of accessing material / teaching materials from lecturers, the existence of unlimited digital library features that are useful for storing data, the preview feature, and the presence of "Filter by post search option". The five indicators are measured on a Likert scale namely Strongly Agree (4), Agree (3), Less Agree (2) and Disagree (1). Table 1 below shows how high the preference of students to use edmodo as a resource for resource sharing based on the five indicators.

Table 1. Preferences of Students Using Edmodo as Resources Sharing

\begin{tabular}{|l|r|r|}
\hline Students' Preferences & Mean & Level \\
\hline $\begin{array}{l}\text { Ease of identifying teaching } \\
\text { materials }\end{array}$ & 2,90 & Agree \\
\hline $\begin{array}{l}\text { Ease of accessing teaching } \\
\text { materials from lecturer }\end{array}$ & 3,20 & Agree \\
\hline $\begin{array}{l}\text { There are unlimited digital library } \\
\text { features that are useful for storing } \\
\text { data }\end{array}$ & 3,13 & Agree \\
\hline $\begin{array}{l}\text { The existence of "filter by post } \\
\text { search option }\end{array}$ & 2,63 & Agree \\
\hline The existence of preview feature & 3,10 & Agree \\
\hline Total & 2,99 & Agree \\
\hline
\end{tabular}

Table 1 shows the preferences of students using edmodo as a resource sharing with lecturers, students and between students. The results of data analysis from the questionnaire showed that students agreed to use the resources sharing function in Edmodo such as digital libraries, teaching materials and others easily and quickly. Students also emphasized that the ease of accessing material / material from lecturers that can be downloaded from edmodo is the main reason students use edmodo.

\subsection{Student Preferences Using Edmodo Related Activities on the Edmodo Platform}

To measure the level of student preferences regarding edmodo related activities on this platform, there are 5 indicators used namely the discussion / forum feature to communicate with lecturers, the discussion / forum feature to communicate with my friends, ease of accessing video files, slides and the others sent by lecturers, easy access to video files, slides and others sent by friends, and the existence of online quiz features. The five indicators are measured on a Likert scale namely Strongly Agree (4), Agree (3), Less Agree (2) and Disagree (1). Table 2 below shows how high the preferences of students using edmodo related to activities on the edmodo platform based on the five indicators.

Table 2. Preferences of Students Using Edmodo Related Activities on The Edmodo Platform

\begin{tabular}{|l|c|c|}
\hline \multicolumn{1}{|c|}{ Students' Preferences } & Mean & Level \\
\hline $\begin{array}{l}\text { There is a discussion or forum } \\
\text { feature to communicate with } \\
\text { lecturer }\end{array}$ & 2,86 & Agree \\
\hline $\begin{array}{l}\text { There is a discussion or forum } \\
\text { feature to communicate with } \\
\text { friends }\end{array}$ & 2,90 & Agree \\
\hline $\begin{array}{l}\text { Ease of accessing video files, slides } \\
\text { and others sent by lecturers }\end{array}$ & 3,43 & Agree \\
\hline $\begin{array}{l}\text { Ease of accessing video files, slides } \\
\text { and others sent by lecturers }\end{array}$ & 3,36 & Agree \\
\hline Online quiz feature & 3,06 & Agree \\
\hline Total & 3,12 & Agree \\
\hline
\end{tabular}

Table 2 shows the preferences of students regarding their activities on Edmodo. From the 5 indicators used, the preference of students to use edmodo is because of its ease of accessing files in the form of docx, videos, slides and others sent by lecturers. Discussion forums have the lowest mean value because students more often use what sup (WA) with their lecturers and friends. They revealed that they were not always online and also did not access Edmodo every time, so they rarely communicated using these features.

\subsection{Student Preferences Using Edmodo Related to "Support"}

To measure the level of student preferences regarding edmodo related support provided by the edmodo platform, there are 4 indicators used namely online help desk, communication between lecturers and students is very fast, there is an appointment feature, communication between students is very fast. The four indicators are measured on a Likert scale namely Strongly Agree (4), Agree (3), Less Agree (2) and Disagree (1). Table 3 below shows how high 
the preferences of students using edmodo related to support on the edmodo platform based on the four indicators.

Table 3. Student Preferences for Using Edmodo Related To Support on The Edmodo Platform

\begin{tabular}{|c|c|c|}
\hline Students' Preferences & Mean & Level \\
\hline The existence of online help desk & 2,76 & Agree \\
\hline $\begin{array}{l}\text { Communication between } \\
\text { lecturers and students is very fast }\end{array}$ & 2,63 & Agree \\
\hline There is an appointment feature & 2,20 & Agree \\
\hline $\begin{array}{l}\text { Communication between } \\
\text { students is very fast }\end{array}$ & 2,70 & Agree \\
\hline Total & 2,57 & Agree \\
\hline
\end{tabular}

Table 3 shows that students really like edmodo because of the online helpdesk feature that can ask at any time the obstacles encountered in using edmodo. In addition, communication between students who are fast response also encourages students to use edmodo media in learning. However, the appoinment feature has the lowest mean which means that students rarely make appointments with lecturers through edmodo because they prefer the use of WA when making appointments with lecturers and they assume that lecturers respond faster via WA compared to using edmodo.

\subsection{Student Preferences Using Edmodo related to Evaluation with Edmodo}

To measure the level of student preferences regarding edmodo related to the support provided by the edmodo platform, there are 4 indicators used, namely the presence of an assignment feature that can be used by lecturers and students to send assignments, the assigment feature allows students to respond to assignments sent by other students, icons used by lecturers as feedback to motivate students, and the presence of "badges" features provided by lecturers that can motivate students. The four indicators are measured on a Likert scale namely Strongly Agree (4), Agree (3), Less Agree (2) and Disagree (1). The following table 4 shows how high the preferences of students using edmodo related to the evaluation tools on the edmodo platform based on the four indicators.

Table 4. Student Preferences for Using Edmodo Related To Evaluations on The Edmodo Platform

\begin{tabular}{|l|c|c|}
\hline Students' Preferences & Mean & Level \\
\hline $\begin{array}{l}\text { The presence Assignment features } \\
\text { that can be used by students to } \\
\text { submit assignments }\end{array}$ & 2,87 & Agree \\
\hline
\end{tabular}

\begin{tabular}{|l|c|c|}
\hline Students' Preferences & Mean & Level \\
\hline $\begin{array}{l}\text { The presence of an assignment } \\
\text { feature allows students to respond } \\
\text { to assignments sent by other } \\
\text { students }\end{array}$ & 2,77 & Agree \\
\hline $\begin{array}{l}\text { The icons are used by lecturers as } \\
\text { feedback to motivate students }\end{array}$ & 3,00 & Agree \\
\hline $\begin{array}{l}\text { The icons are used by lecturers as } \\
\text { feedback to motivate students }\end{array}$ & 2,87 & Agree \\
\hline \multicolumn{1}{|c|}{ Total } & 2,87 & Agree \\
\hline
\end{tabular}

Table 4 shows that students like Edmodo because lecturers often use icons that can motivate them. In addition, the presence of feature assignments also makes it easy for them to send assignments given by the lecturer. Besides that, the negative side of the ease of sending this assignment is that other students can easily do plagiarism / copying the assignments sent by other students.

\section{CONCLUSION}

This research shows that Edmodo increases student's motivation in audit courses because Edmodo is very interesting media to communicate with their lecturer and their friends. Also, Edmodo based learning is very easy to use because it is similar with Facebook. Students also emphasized that the ease of accessing material / material from lecturers that can be downloaded from Edmodo is the main reason students use Edmodo.

\section{REFERENCES}

[1] S. S. Bawaneh, Does using computer technology improve students ' performance? Evidence from a management accounting course, J. Bus., vol. 2(10), 2011, pp. 266-275.

[2] M. Prensky, Digital Natives, Digital Immigrants Part 1, Horiz., vol. 9(5), 2001, pp. 1-6.

[3] R. Seethamraju, Information technologies in accounting education, Proc. 2010 Int. SIGED IAIM Conf., 2010.

[4] K. Balasubramanian, V. Jaykumar, and L. N. Fukey, A Study on 'Student Preference towards the Use of Edmodo as a Learning Platform to Create Responsible Learning Environment,' Procedia - Soc. Behav. Sci., vol. 144, 2014, pp. 416-422.

[5] G. E. Veronika Végh, Zsolt B. Nagy, Csilla Zsigmond, The Effects Of Using Edmodo In Biology Education On Students Attitudes Towards Biology And ICT, J. Probl. Educ. 21 Century, vol. 75(5), 2017, p. 483.

[6] F. F. Hanum et al., The Use of Edmodo in Civic Education to Strengthen the Honesty of Senior High School Student, Int. J. Educ. Sci. Res., vol. 8(1), 2018, pp. 37-44. 